April 9, 2004

\title{
Econometric Methods in Staples
}

Orley Ashenfelter, David Ashmore, Jonathan B. Baker, Suzanne Gleason \& Daniel S. Hosken*

\begin{abstract}
$\underline{\text { Abstract }}$
Econometrics played a major role in the investigation and litigation of the Federal Trade Commission's (FTC) successful challenge to the proposed merger between two office superstore chains, Staples and Office Depot. Our goal in writing this essay is to describe the econometric issues at stake in evaluating the FTC's central claim that the price charged by office supply superstores was related to the number and identity of superstore firms participating in the market. Similar statistical models were relied upon by the FTC and the merging firms to analyze pricing. Our discussion of these models highlights the advantages and disadvantages of alternative approaches to analyzing a panel data set: cross-sectional estimates versus fixed effects estimates. We also describe and evaluate modeling choices that appeared to have substantial influence on the empirical results.
\end{abstract}

\footnotetext{
* The authors are Professor of Economics, Princeton University; Partner, Ashenfelter \& Ashmore; Professor of Law, American University; Assistant Professor of Economics, Trinity College; Deputy Assistant Director for Economic Policy Analysis, Federal Trade Commission, respectively. Ashenfelter was an econometric witness for the FTC in the Staples case; Ashmore assisted Ashenfelter, and the remaining authors worked on the case for the FTC. The views expressed are not necessarily those of the FTC or any individual Commissioners.
} 


\section{Introduction}

Econometrics played a major role in the investigation and litigation of the Federal Trade Commission's (FTC) successful challenge to the proposed merger between two office superstore chains, Staples and Office Depot. The pretrial discovery sparring evolved into an econometric tournament: each side responded to the studies developed by the other side with a counter analysis of the same data, and drew additional responses in turn, all the way up to and even beyond the start of the preliminary injunction hearing. For the FTC, the econometric effort involved six Ph.D. economists working full time on data analysis for several months, with other economists also chipping in. ${ }^{1}$ This case likely still holds the record for the most extensive commitment of resources to econometric analysis in government antitrust litigation, and by a wide margin.

Relative to the attention given to econometrics by the parties, the district court's opinion enjoining the proposed acquisition is disappointing. ${ }^{2}$ The opinion never mentions the econometric evidence, and the judge later stated that the internal company documents were "more convincing” than the econometric evidence proffered by the government. ${ }^{3}$ Nevertheless, the district court judge demonstrably relied on one econometric study, as it offered the only evidence in the trial record that supported the court's factual finding concerning Staples' historical pass-through rate. ${ }^{4}$ Moreover, the econometric evidence was probably critical to the FTC's decision to challenge the case in court: it is unlikely that the Commission would have been persuaded by the pricing evidence in the documents to limit the market it alleged to the office superstore retail channel had that evidence not been confirmed through systematic empirical analysis. Accordingly, and notwithstanding the district court's primary reliance on documentary rather than statistical evidence, econometric analysis was important in investigating and litigating the FTC’s challenge to the Staples/Office Depot merger.

Our goal in writing this essay is to describe the econometric issues at stake in evaluating the FTC’s central claim that the price charged by office supply superstores was related to the number and

\footnotetext{
1 This figure does not include the equally large number of FTC economists working to investigate the proposed merger and provide litigation support who were not involved in the econometric analysis, nor the many economists involved in econometric analysis on behalf of the merging firms.

2 Federal Trade Commission v. Staples, Inc., 970 F. Supp. 1066 (D.D.C. 1997) (granting the FTC's motion for a preliminary injunction).

3 Ken Auletta, World War 3.0: Microsoft and Its Enemies (2001), at 221.

${ }^{4}$ The government devoted substantial resources to estimate Staples' pass through rate. We do not discuss the pass through study in this paper, but it is described in detail in Orley Ashenfelter, David Ashmore, Jonathan B Baker, Signe-Mary McKernan, "Measuring the Price Effects of a Merger: Evidence on Cost Pass-Through Rates from the Staples/Office Depot Case” (unpublished manuscript, October 2001).
} 
identity of superstore firms participating in the market. ${ }^{5}$ The FTC argued that Staples systematically charged its customers the least in cities in which the two other superstore chains, Office Depot and OfficeMax, were also present; charged higher prices in cities in which it faced only one other superstore chain rival; and charged the most in cities with no other office supply superstore chain present. This asserted empirical regularity was at the heart of the government's prediction that the loss of competition from Office Depot through merger would result in higher prices for office supply customers.

Similar statistical models were relied upon by the FTC and the merging firms to analyze pricing. Both sides employed reduced form equations, which explained Staples prices by variables treated as exogenous or predetermined. ${ }^{6}$ Our discussion of these models highlights the advantages and disadvantages of alternative approaches to analyzing a panel data set: cross-sectional estimates versus fixed effects estimates. We will also describe and evaluate modeling choices that appeared to have substantial influence on the empirical results.

\section{Case Background}

Prior to 1986, small business and home office customers purchased office supplies primarily through small independent stationers, warehouse clubs and mail order firms. In 1986, Staples, located in the Northeast, and Office Depot, located in Florida, pioneered the office supply superstore (OSS) concept almost simultaneously. Only the office supply superstores offered “one-stop shopping” providing an inventory, breadth of products and convenience not available elsewhere, including other retailers like BestBuy, Wal-Mart, Target, computer stores and independent stationers.

By late 1996, only Staples, Office Depot and OfficeMax remained strong OSS competitors. Office1Superstore, the lone other OSS chain, was small and on the verge of exiting the market. Although the three remaining OSS rivals each had strong regional positions, they were beginning to expand into each other's territories as the chains were growing rapidly. Staples and Office Depot competed directly in more than forty metropolitan areas.

\footnotetext{
${ }^{5}$ A more extensive and technical treatment of the issues discussed here can be found in Suzanne Gleason and Daniel Hosken, Econometrics in FTC versus Staples/Office Depot (unpublished manuscript, April, 2002). The back and forth between the econometric experts in the case is described in Jonathan B. Baker, Econometric Analysis in FTC v. Staples, 18 J. Pub. Pol. \& Marketing 11 (1999).

${ }^{6}$ Our discussion of the econometric analysis in Staples focuses upon the analysis of pricing. We do not discuss other econometric studies conducted by either side during the litigation, including an analysis of stock market responses to the merger announcement; an analysis of the effect of entry by superstore rivals and non-superstore rivals on Staples revenues; an analysis of Staples' price-cost margins; or the estimation of Staples' cost pass-through rate.
} 
On September 4, 1996, Staples and Office Depot announced their plan to merge. At that time, each had approximately 500 stores and their combined annual sales exceeded \$10 billion. In April 1997, the Federal Trade Commission (FTC) voted to oppose the transaction. In its complaint, the FTC alleged a product market consisting of “consumable office supplies sold through office supply superstores,” and identified forty-two individual geographic markets in which it anticipated consumer harm resulting from the merger. Consumable office supplies, defined as those items repeatedly purchased by consumers (and thus quickly consumed), account for only 50\% of OSS revenue. The remainder of OSS revenue arises from business services, office furniture and computer sales. While Staples and Office Depot argued that all products sold by their stores should be included in the product market, the data used by both the defendant and the government in the pricing studies described in this essay contained information about consumable office supplies only.

The FTC won a preliminary injunction against the merger in US District Court in June 1997. Subsequently, Staples and Office Depot abandoned the proposed transaction.

\section{Non-econometric Evidence}

Although econometric evidence was an important part of the merger litigation, it played a secondary role to the documentary evidence. The government relied primarily on industry and firm documents to show direct competition between the parties, and used documentary evidence to justify choices made in specifying the econometric models. Econometric evidence was used to confirm the observations about pricing made by firm executives and other industry observers, and to estimate the likely level of harm resulting from the merger.

An Industry Update prepared by investment analysts at Prudential Securities in March 1996 suggested the importance of direct competition between Staples and Office Depot in keeping prices low. The report described the result of comparison-shopping a bundle of goods at OSS chains in two towns in New Jersey, Paramus and Totowa. In Paramus, a “two-player” market served by Staples and OfficeMax, the Prudential analyst found that prices were approximately 5\% higher than in Totowa, a “three-player” market served by all three OSSs. The analyst attributed the price difference to the absence of competition from Office Depot in Paramus. 
Documentary evidence presented by the FTC during litigation indicated that Staples considered the presence of Office Depot in its price setting decisions. Moreover, as shown in Figure 1, ${ }^{7}$ Staples' prices were highest in geographic regions where it faced no competition from OSS chains, which it termed 'non-competitive.' Lower average prices prevailed in markets where Staples and Office Depot competed directly, with only small price differences between a Staples-Office Depot market and a threeplayer one. Company documents indicated that both companies grouped metropolitan areas into price zones $^{8}$ according to the level of OSS competition in the market, almost entirely without regard for the extent of rivalry from nonsuperstore retailers of office supplies. In addition, Staples would reclassify a metropolitan area's price zone in response to the entry of a competing OSS chain to lower price, but would not do so in response to the entry of non-superstore retailers. A simple comparison between prices in cities where the two merging OSS chains competed and prices in cities where they did not suggested that the merger, by removing Office Depot from the market, would raise price on average by about $9 \%$ in those cities served by both firms. ${ }^{9}$

\section{Econometric Issues}

The empirical pricing studies performed in the Staples case were important for at least two reasons. First, the econometric analyses provided a highly-publicized case study illuminating the relative merits of cross-sectional studies (which examine differences in prices across a number of regions at a point in time), ${ }^{10}$ and studies that use panel data (examining prices in the multiple regions over time). While the differences between these types of studies were well known to empirical economists, they had not previously been highlighted in antitrust practice. Second, the empirical methodology developed in the Staples case has influenced the way economists conduct studies to measure the effects of market structure on price using historical data in service markets, such as retailing. In the remainder of this section we discuss strengths and weaknesses of cross-sectional studies and those that use panel data. We then describe the key features of the pricing studies employed in the Staples/Office Depot merger case: the construction of the price index, the statistical models estimated,

\footnotetext{
${ }^{7}$ Figure 1 is a re-creation of an exhibit typical of many used by the FTC at the preliminary injunction hearing to show how Staples' pricing was higher in markets with fewer OSS chains.

${ }^{8}$ A price zone is a geographic area within which all of a chain's stores charge the same or similar prices. This geographic area generally corresponds to a metropolitan area or a newspaper distribution zone.

9 Serdar Dalkir and Frederick R. Warren-Boulton, Prices, Market Definition, and the Effects of Merger: Staples-Office Depot (1997), in The Antitrust Revolution 143, 152 (John E. Kwoka \& Lawrence J. White, eds., 3d 3d. 1999)

${ }_{10}$ Early empirical industrial organization economists typically employed a cross-sectional modeling approach to investigate the relationship among market structure, conduct, and performance.
} 
the important differences in methodology used by the government and the defendants. Finally, we discuss some potentially important econometric issues that were not addressed in trial because of time constraints.

\section{A. Cross-Section vs. Fixed Effects Estimates in Panel Data}

The panel data set analyzed by both sides in the Staples litigation tracked the prices set by individual stores over time. The data included observations on the prices charged by each store at different times, ${ }^{11}$ and observations on prices at different stores (both in the same city and in different cities) at any one time.

These data permit two different approaches to identifying the way prices change with variation in market structure. Both statistical approaches attempt to understand how Staples' pricing is affected by competition from Office Depot, holding constant competition from other retailers. The cross-sectional approach makes use of comparisons across regions at a particular point in time to answer this question. The statistical model compares Staples markets with and without Office Depot to determine what effect Office Depot has on Staples’ pricing. Similarly, the cross-sectional model uses information on different market structures across regions to determine the effect of OfficeMax on Staples' pricing and the effect of other types of retailers (e.g., Wal-Mart, Target, BestBuy, etc). The primary advantage of the crosssectional approach comes where, as with the data available in the Staples case, market structure varies substantially across regions, and there are a large number of regions in the data. Then the data provide multiple comparisons from which the effects of market structure on price may be isolated.

But comparisons of prices across regions can only isolate the effects of market structure if they control for other influences on price that may vary from one store to the next. For example, the economists on both sides in Staples agreed that their analyses must take into account differences across regions in the presence of non-superstore vendors of office supplies, such as discount mass merchandisers like Wal-Mart and warehouse club stores like PriceCostco. Otherwise, the statistical analysis might (spuriously) seem to associate higher prices with decreased superstore rivalry, when in fact the culprit is a reduction in non-superstore rivalry. This problem would arise if non-superstore rivalry is important in determining office superstore prices, and if, in the data, cities served by fewer

\footnotetext{
${ }^{11}$ The data from Staples consisted of aggregate revenue and units sold by each Staples store for each stock keeping unit (SKU) and time period. A stock keeping unit is a finely-specified product definition chosen by the firm for internal inventory management uses. For example, different SKUs might be employed for the red ink and blue in models of a particular brand
} 
superstore chains were also commonly served by fewer non-superstore vendors of office supplies. In their econometric studies both the government and the defendants controlled for competition from the major types of non-OSS competitors, e.g., discounters, club stores, and computer superstores.

It may not always be possible, however, to observe and control for all ways in which regions can differ, affecting prices. For example, differences in zoning or traffic congestion may lead to variation in costs across locations, which may be difficult to measure. When important variables affecting price in different regions cannot be observed, a cross-sectional analysis of pricing may mislead. Prices may be higher in regions in which rival superstores are absent not because of that fact, but because those are also regions in which costs are high in ways that cannot be observed and accounted for in the statistical analysis. The possibility of this “omitted variable” bias creates the main potential disadvantage of employing cross-sectional estimates.

As an alternative to making inferences about the price effects of market structure from (crosssectional) comparisons across regions, it may be possible, using panel data, to make such inferences by exploiting variation in market structure at fixed locations over time. This approach uses information on changes in market structure within a location over time, e.g., Office Depot entering a Staples city or Office Depot increasing its presence in a Staples city, to measure the effect of Office Depot on Staples’ pricing. As with cross-sectional comparisons, the panel approach can also be used to measure the effect of OfficeMax and other types of retailers on Staples’ pricing. This alternative to the cross-sectional model is often termed the "fixed effects" model because of the econometric technique used to analyze panel data. Whether a cross-sectional or fixed effects approach is employed, the question being is the same: how does competition from one retailer (Office Depot) affect the pricing of its rival (Staples)?

The primary advantage of the fixed effects model comes where, as is plausible with respect to the retail sale of office supplies, most unobservable factors affecting price - the factors that create the primary disadvantage of the cross-sectional approach are unlikely to vary much during a short time period, such as the twenty months over which data were available in the case. For example, zoning or traffic congestion are likely similar from one month to the next within most metropolitan areas, varying more across cities than within them over time. Accordingly, the price effects of changes in market structure can be inferred from the way Staples’ prices change in a given region over time with the entry or exit of superstore rivals, after controlling for 
observable changes in other variables (like the entry or exit of non-superstore vendors), with limited likelihood that the results are infected by the misleading effects of spurious correlations between price and unobservable factors. In short, the fixed effects model can often be expected to address the primary disadvantage of the cross-sectional model.

The fixed effects model can only be employed if there is sufficient time series variation in the data to permit precise estimates of the relationship between price and market structure. In many panel data sets, there is more variation across regions than within regions over time. For example, in Staples, relatively few cities experienced either an Office Depot entering a Staples location or a Staples entering an Office Depot location, while there were a larger number of regions that either always had or never experienced competition between Staples and Office Depot during the sample period. When the time series variation in the data is limited, fixed effects estimates of the price effects of market structure may be less precise than estimates based upon the cross-sectional aspect of the data. ${ }^{12}$ Moreover, while fixed effects models tend not to be prey to "omitted variables" bias, they tend to exacerbate another econometric problem, “errors in variables” bias. ${ }^{13}$ The errors in variables problem is the difficulty of detecting statistically the influence of an explanatory variable when that variable is measured with error. Random measurement error in an explanatory variable (e.g. in the variable accounting for the presence of a competitor) will bias its parameter estimate towards zero; that is, if an explanatory variable is randomly mis-measured the estimated magnitude of its importance will be understated. In general, the primary disadvantage of fixed effects models is their tendency to exacerbate the potential for bias from measurement error. $^{14}$

If a cross-sectional model and a fixed effects model generate different estimates of the price effects of market structure, which result is to be preferred? One way to approach this question is to evaluate the likely importance of the advantages and disadvantges of each in the available data. The cross-sectional model is at its best when the data contain observations on a large number of regions, with

\footnotetext{
${ }^{12}$ In contrast, there was a lot of variation in the amount of competition between Staples and Office Depot during the sample period. That is, the data contained many examples of Office Depot and Staples expanding their presence in cities also served by their rival. In consequence it was possible to measure the effect of increased competition from Office Depot on Staples' prices with reasonable precision.

13 Zvi Griliches, Sibling Models and Data in Economics: Beginnings of a Survey, 87 J. Pol. Econ. S37 (1979); Orley Ashenfelter \& Alan Kreuger, Estimates of the Economic Returns to Schooling from a New Sample of Twins, 84 Am. Econ. Rev. 1157 (1994); Zvi Griliches \& Jerry A. Hausman, Errors in Variables in Panel Data, 31 J. Eocnometrics 93 (1986).

${ }^{14}$ Another potential disadvantage of fixed effects models arises from the common possibility that the random variation in the dependent variable (the error term in the regression model) may be correlated over time. Under such circumstances, the precision of parameter estimates may be overstated (confidence intervals on the parameters understated) unless
} 
substantial variation in market structure across those regions, permitting precise estimates of parameters. It is also most persuasive when there is reason to think that "omitted variable” problems are small, perhaps because good measures of cost variation across regions are available or because there is little reason to think that unobservable cost variables are important in determining prices. The fixed effects model, in contrast, is most persuasive when the data contain many examples of entry or exit of rival firms over time, when unobservable influences on price are unlikely to vary over time in any given location, and when key independent variables (e.g., OSS competition) are thought to be measured precisely.

In some settings, however, the data will only permit one approach; ${ }^{15}$ under such circumstances, non-econometric evidence would likely provide the best source of information for assessing the significance of its potential disadvantages. In other settings, in which both approaches are feasible and the omitted variable and measurement error biases would be expected to go in different directions, the cross-sectional and fixed effects approach may generate similar estimates, suggesting that neither of these potential methodological problems is substantial in the data.

Both cross-sectional and fixed effects regressions were employed in the econometric analysis of pricing during the Staples litigation. But the interpretation of these statistical analyses did not turn on a choice between these methods. In fact, both the cross-sectional and fixed effect models yielded similar results. ${ }^{16}$ Because the merging firms emphasized their concern with the potential for omitted variable bias in cross-sectional studies, both sides conducted most of their analysis using fixed effects models. For this reason, we limit our detailed discussion to the results from the fixed effect models.

\section{B. Construction of the Price Index}

The majority of econometric analyses presented in litigation were carried out using historical sales data provided by Staples in response to the government's requests for information pursuant to the (Hart-Scott-Rodino) premerger notification statute. Early in the investigation, the economist working for the merging firms constructed a price index based on a weighted average of product prices, in order to facilitate the analysis of pricing on the over 7000 stock-keeping units (SKUs) of consumable office

autocorrelation in the errors is accounted for in the estimation. An analogous problem of correlation in the error across neighboring locations could arise in cross-sectional analyses, but the correlation over time is often more severe.

15 For example, in analyzing supermarket or hospital competition, there may be little variation in market structure over time. If so, only a cross-section estimate of the price effect of market structure would be available.

${ }^{16}$ The government presented cross-sectional and fixed effects estimates of the price increase from merger of $7.1 \%$ and $7.6 \%$, respectively. 
supplies in a typical Staples store. ${ }^{17}$ The price index was subsequently adopted by government economists as well.

To construct the price index, Staples' SKUs were grouped into four categories corresponding to the frequency with which Staples price-checked the item. ${ }^{18}$ The first category, "price-sensitive items" (PSIs), consisted of items which consumers bought often and in large quantities such as copier paper. Consumers are likely to choose a retailer based on the price of these items, so Staples price checked them often. Consumer attention, in addition to a price guarantee, ${ }^{19}$ made it costly to misprice this set of items. A subset of PSIs, called "leadership items," were sold at low margins and used as price leaders to build store traffic. This subset consisted of primarily low priced items such as pencils, pens and tape. The third category, “non-price sensitive items” (non-PSI), included items similar to PSIs, but were price-checked less frequently. Finally, “invisible items” consisted of items consumers purchased (such as green ink pads) that were rarely price-checked. A separate price (sub)index was calculated for each of these four categories and these were combined to find a storewide price index.

More formally, the price (sub)index for store i at time t for category k was the weighted average,

\section{Equation 1}

$$
p_{i t k}=\sum_{j \in k} w_{j} * p_{i t j}
$$

where $w_{j}$ is the quantity weight corresponding to SKU $j$ and $p_{i t j}$ is the price of the $j^{\text {th }}$ item at the $i^{\text {th }}$ store at time t. The storewide price index was defined to be

\section{Equation 2}

$$
\ln p_{i t}=\sum_{k} \omega_{k} * \ln p_{i t k},
$$

where $\omega_{\mathrm{k}}$ is the proportion of revenues from category $\mathrm{k}, \mathrm{k}=1$ to 4 .

\section{Econometric Model and Results}

The basic model used by both sides of the case took the following form:

\footnotetext{
${ }^{17}$ For more details concerning the methodology for constructing the price index, see Jerry Hausman, New Goods, the CPI, and the BLS (unpublished manuscript, 1996).

${ }_{18}^{18}$ Price checking involved visiting competing stores to determine their current pricing.

${ }^{19}$ Staples paid consumers $150 \%$ of the price difference between Staples' price and a competitor's price.
} 


\section{Equation 3}

$$
\ln p_{i t}=\alpha_{i}+f(\text { competition })+\sum_{t} \gamma_{t} * D_{t}+e_{i t}
$$

where $\alpha_{\mathrm{i}}$ is a store-level fixed effect, ${ }^{20} \mathrm{f}(\bullet)$ is a function of the level of retail competition near a Staples store, $\mathrm{D}_{\mathrm{t}}$ is a dummy variable for each time period $\mathrm{t}$, and $\mathrm{e}_{\mathrm{it}}$ is a disturbance term with a mean of zero. The store-level fixed effect accounts for systematic but unmeasurable differences in costs of doing business between stores. Areas with higher costs of retailing are likely to have higher prices, all else equal. If so, and if these costs are correlated with the level of competition, omission of store-level fixed effects would tend to bias the relationship between a store's price index and the level of competition nearby.

Both the government and the merging firms employed this general model to estimate the likely consumer harm resulting from the merger. But the economists on the two sides produced very different results. Plaintiff's Exhibit (PX) 400, entered into the record by the FTC and reproduced in Table 1, summarizes the econometric results of the price studies. The exhibit was designed by the government's expert to explain the differences in estimated price effects between the two sides. The Simulated Price Change row answers the question: how much would prices increase in places where Staples and Office Depot overlap if all Office Depot stores were converted to Staples stores? Model 1 corresponds to the government's replication of the merging parties' estimate of the price effect resulting from the merger: an average price increase of $1.1 \%$ in overlap markets. Model 7 corresponds to the government's estimate, a price increase of $8.6 \%$. The intervening models demonstrate the impact of differences in assumptions made by the two on the simulated price effect. ${ }^{21}$ The models differed in the implied model of retailing, geographic inclusion and the calculation of consumer harm. We discuss these in turn.

The level of retail competition near a Staples store is hard to quantify. Firm documents provided data on the number and opening dates of the three major OSS chains, but did not include information on non-OSS competition. Data were collected on the presence of mass merchandisers (Wal-Mart, Target and Kmart), computer superstores (BestBuy, Computer City, and CompUSA), and warehouse clubs (PriceCostco, BJ's, and Sam’s Club). However, time constraints did not allow either side to collect data

\footnotetext{
${ }^{20}$ The store-level fixed effects are time invariant dummy variables equal to one for store i and zero otherwise.

${ }^{21}$ Two minor differences between the merging firms' results and the government's are not discussed in the text: differences in the unit of observation and differences in the calculation of the dependent variable. While both sides used store level observations, the government used monthly observations and the parties used weekly observations. Second, despite attempts to follow an identical price index calculation, the price indices calculated differed slightly due to missing data issues. These differences had minor impacts on the various estimated price effects (no more than $0.3 \%$ ).
} 
on local stationers. All the econometric results presented during the litigation control for those competitors for which information was available.

The method of controlling for competition near a Staples store differed between the government and the parties. The defendant's expert's measure of local competition was based on the distance between rival stores. That is, retailers were assumed to base their pricing decisions on the number of competitors very close (within 5 miles), somewhat close (5-10 miles) and somewhat distant (10-20 miles) from their stores. The underlying theory is that a firm's pricing is constrained by the ability of consumers to travel to a competing store, and that travel time is closely related to distance. If so, the farther the typical consumer has to travel, the higher the price a retailer can charge. The empirical equation corresponding to this model of retail competition is as follows:

\section{Equation 4}

$$
\begin{aligned}
\ln p_{i t} & =\alpha_{i}+\sum_{t} \gamma_{t}+\sum_{z}\left[\theta_{1 z} D 5_{i t}+\theta_{2 z} D 10_{i t}+\theta_{3 z} D 20_{i t}\right] \\
& +\sum_{z}\left[\theta_{4 z} \ln \text { store } 5_{i t}+\theta_{5 z} \ln \text { store } 10_{i t}+\theta_{6 z} \ln \text { store } 20_{i t}\right]+e_{i t},
\end{aligned}
$$

where $\mathrm{D} 5_{\mathrm{it}}, \mathrm{D} 10_{\mathrm{it}}$ and $\mathrm{D} 20_{\mathrm{it}}$ are "absence" dummy variables equal to one if retailer $\mathrm{z}$ does not have a store within 5, 10, or 20 miles, respectively, of store $i$. The variables $\ln$ store $5_{i t}$, $\ln$ store $10_{\text {it }}$ and $\ln$ store $20_{\mathrm{it}}$ are equal to the natural logarithm of the number of retailer z's stores within 5, 10, and 20 miles of store i. ${ }^{22}$ These variables create a "bullseye" picture: the competitive constraint posed by an Office Depot store is measured by where the store falls within concentric circles drawn around each Staples location.

The government conceived of a firm charging similar prices within a broad geographical area, such as a Metropolitan Statistical Area (MSA), rather than customizing prices to the exact competitive conditions of each individual store. ${ }^{23} \mathrm{~A}$ firm may price this way to avoid the costs of determining prices on a store by store basis or because of economies in advertising for a broader area. Office supply

\footnotetext{
${ }^{22}$ Because the natural log of zero is not defined, the government and the defendants used the absence dummies described above to estimate the price effect of not observing a given competing retailer. When the number of retail stores was positive, the absence dummy took on the value zero, and the effect of competition was measured as the log of the number of that retailer's stores.

${ }^{23}$ The government measured competition in MSAs with the exception of some very large MSAs, such as New York, where the government used PMSAs. The geographic regions that make up MSAs are defined by the Census and typically include entire counties, including regions arguably outside of a metropolitan area. Thus, in some cases stores outside of a metropolitan area were classified as in the metropolitan area (because they were in the same MSA). This misclassification likely reduced the estimated price effects because stores that faced little superstore competition (those on the outskirts of an MSA) were placed in the same region as those that faced much competition (those located near most of the population in the MSA).
} 
superstore customers may have a wider travel range than for other retailers such as grocery stores; they may receive an ad at home but shop at a Staples near the office expecting to see the same advertised specials. Thus, if newspaper advertising blankets a metropolitan area, then every Staples store may be forced to respond to newspaper promotions undertaken by Office Depot, regardless of the physical proximity of the two firms' retail locations within the region. Consistent with this perspective on retail competition, Staples' documents indicate that Staples charged similar prices within price zones that corresponded closely to MSAs. Under this retail scenario, the pricing equation becomes, for each Staples store, i, in each time period, $t$,

\section{Equation 5}

$$
\ln p_{i t}=\alpha_{i}+\sum_{z} \beta_{1 z} D_{z i t}+\sum \beta_{2 z} \ln \text { store }_{z i t}+\sum_{t} \gamma_{t} D_{t}+e_{i t}
$$

where the $\mathrm{D}_{\mathrm{zit}}$ is an "absence” dummy variable equal to one if retailer $\mathrm{z}$ is not in the MSA in time period $\mathrm{t}$ and $\ln$ store $_{\mathrm{zit}}$ is the natural logarithm of the number of retailer z's stores in the MSA at time t.

Implicitly this model assumes that each store from a competitor chain located within the area has the same impact on the Staples store pricing, while the concentric circle method allows closer stores to have a different (larger) impact.

Both methods are in principle reasonable approaches to modeling retail pricing. As can be seen from PX-400, however, the estimated price effects from these two pricing models were very different. Comparing Model 2, using the concentric circle method, with Model 5, using the MSA-based method, it is apparent that the MSA-based method indicated a substantially higher price change than the concentric circle method (4.0\% as opposed to $0.8 \%)$, everything else held constant.

Models 3 and 4 evaluate these approaches to modeling the impact of competition for explaining Staples pricing behavior by including both sets of competitor variables. Model 3 reports the simulated impact when either set of variables indicates that a Staples store faces Office Depot competition and Model 4 does the same when both sets indicate that a Staples store faces Office Depot competition. Both sets of variables enter with statistical significance, and the simulated price effects from this exercise fall in between the estimates generated by both sides. Thus, to some extent both measures of retail competition appear to be mis-measured. ${ }^{24}$

\footnotetext{
${ }^{24}$ Neither measure of retail competition fully captures the variation across stores in the opportunity cost of buyer substitution between stores, which may be a source of differences in the elasticity of store-specific demand and, consequently, differences in store pricing. For example, neither measure entirely reflects the distribution of travel times facing customers choosing between competing stores. In more congested areas, stores must be closer together (in the concentric circle method) or more
} 
The government and the parties also differed in the geographic inclusiveness of their models. The government estimated a single nationwide price equation, under the assumption that the manner in which Staples responded to competition from other retailers would not differ in different regions of the country. This assumption was consistent with the Staples pricing documents reviewed by the FTC during the investigation. However, the merging firms contended that there were important differences between retail practices in California and the rest of the United States. Their expert estimated two pricing equations, one for California and one for the rest of the US and showed, using a statistical test (Chow test), that the pricing equation differed between California and the rest of the U.S. In consequence, the simulated effects depended upon the treatment of California. Model 6 in PX-400 shows that when the merger is simulated over the subset of the US excluding California, the price effect is $3.7 \%{ }^{25}$ In contrast, in Model 7, with California included, the simulated price effect is $8.6 \%$. To account for the difference in the pricing equation between California and the rest of the US, the government estimated separate equations for the two regions of the country and calculated a weighted average price to estimate the price effect of the merger, yielding a simulated price effect of $9.8 \%$. The weighted average of regional estimates, which takes into account the difference in the California pricing equation, thus generated a higher simulated price effect than that estimated using the unweighted average approach of Model 7.

The final major difference between the two price estimates was in the calculation of consumer harm (the simulated increase in price). The government's expert addressed the question: "How much will prices rise at the average Staples store observed in the sample that experienced competition from Office Depot?” To calculate this number for his original analysis presented in PX-400, he assumed that all Office Depots within an MSA would be converted to Staples stores. He also recalculated the price effects under an alternative assumption, similar to one made by the merging firms' expert, that all Office Depot stores that overlapped with Staples would be closed. For the latter alternative, the estimated price effect of the merger becomes

numerous (in the MSA method) to have the same impact as in a less congested area. Also, neither measure perfectly captures the way the density of newspaper penetration, and thus the impact of newspaper advertising, may vary across the metropolitan area for each store. These measurement issues are likely to have a different impact on the concentric circle competition variables than on the MSA ones, and thus cause the two approaches to yield different simulated price changes. ${ }^{25}$ Simulating the price effect of the merger over a slightly different "rest of the US" subsample, that treats differently a small number of stores not assigned by the merging firms to either regional subsample, yielded a price increase of 5.0\%. 


$$
\Delta p=-\frac{\sum_{t} \sum_{i}\left[\beta_{1, O D}+\beta_{2, O D} \ln \text { Store }_{O D, i, t}\right]}{n_{1}},
$$

where $n_{1}$ is the total number of observations in which there was an Office Depot in a Staples store's MSA and where the sum is taken over all time periods in which a Staples store faced Office Depot competition and across all Staples stores in the MSA. ${ }^{26}$

The merging parties' approach differed from the government's in two important ways. First, the firms' estimate used only the last time period in the study, on the view that the best way to see the price change was to employ the most current measure of competition in each market. Second, the firms asked the question: "how much would prices increase in the average Staples store?" (not "the average Staples store experiencing competition from Office Depot”). For the merging firms, therefore, the price effect of the merger is estimated as:

$$
\Delta p=-\frac{\sum_{i}\left[\beta_{1, O D}+\beta_{2, O D} \ln \text { Store }_{O D, i, T}\right]+n_{2} * 0}{n_{1}+n_{2}},
$$

where $\mathrm{n}_{1}$ is the number of Staples stores which had Office Depots in their MSAs in the final time period, $\mathrm{T}$, and $\mathrm{n}_{2}$ is the number of Staples stores that did not have any Office Depots in their MSAs in the final time period. This price effect will always be lower than the government's estimated price effect because it includes stores that do not face Office Depot competition, and thus are assumed not to experience a change in price. For example, if the numbers of Staples stores that faced Office Depot were equal to the number of Staples stores that did not, the estimated price effect from Equation 7 would be half that found using Equation 6.

Both methods of calculating the price increase from merger have legitimate economic interpretations. Equation 6 corresponds to how much prices would rise at the average Staples store which faced Office Depot competition (and therefore to how much prices would rise in the geographic

\footnotetext{
${ }^{26}$ For simplicity in discussing the differences between the government's and defendant's approach to estimating the price effects of the merger, we use the notation from the government's pricing equation (equation 5). The actual calculation
} 
markets in which harm to competition was alleged by the FTC). Hence, this measure indicates the likely harm those consumers directly affected by the merger would face. Equation 7, however, corresponds to how much prices would change in the average Staples store. This latter measure faciliates the weighing of the harm to competition against any consumer benefit that would arise from merger-related efficiencies, which would be expected to benefit Staples customers in all cities, regardless of whether or not Staples overlaps with Office Depot. Using Equation 7 and a measure of the extent to which the efficiencies from merger would be passed on to consumers, it may be possible to compare the potential harm to consumers in overlap areas from the loss of competition against the potential benefit to consumers in nonoverlap areas from efficiencies.

\section{Econometric Issues not Addressed in Trial}

In a litigation setting, empirical economists gravitate to the analysis of issues that potentially matter to the outcome and have a reasonable likelihood of being understood in a short period of time. In Staples, both sides focused on testing the robustness of the pricing equation to different model specifications, such as those described above, that were straightforward to implement. Two other potentially important issues, however, were not studied as intensively.

First, in estimating the pricing equations, both sides assumed store entry and expansion decisions by OSS chains were exogenous to Staples’ price setting. This may not be correct: it is possible that a high Staples price in a city, for example, makes the stores in that city highly profitable and so encourages entry and expansion by both Staples and its rivals. If so, entry or expansion would be endogenous -- that is, jointly determined with price -- and, in consequence, ordinary least squares estimates of the pricing equations may generate biased estimates of the parameters. Such problems can in principle be addressed by employing instrumental variables techniques, or by estimating an empirical model that describes new store entry or expansion decisions simultaneously with the pricing model. ${ }^{27}$

Second, neither the government nor the merging firms made a substantial formal effort to measure and account for the effects of nonprice competition. Yet retail stores employ many instruments in addition to price in order to attract customers. For example, grocery stores often differentiate

involved different estimated parameters for different regions, and different parameters depending on the pricing equation estimated (equation 4 or 5 ).

27 The FTC staff had preliminary results, not part of the trial record, using instrumental variables techniques to estimate the pricing equations. The resulting simulated price increases were roughly double those based on equations estimated using ordinary least squares. The instruments are described in Jonathan B. Baker, Econometric Analysis in FTC v. Staples, $18 \mathrm{~J}$. Pub. Pol. \& Marketing 11, 17 (1999). 
themselves from the competition by offering more specialties (such as a fresh seafood counter, a bakery, or a gourmet deli) or different services (bagging groceries, self-check out) rather than by price. Moreover, firms may respond to competition on service dimensions as well as on price. Grocery stores may increase the cleanliness of a store or lower the waiting time of customers in response to a new grocery store opening nearby. A more complete analysis of competition among OSS chains would account for variation in service levels along with variation in price.

\section{Conclusion}

The district court enjoined the proposed Staples/Office Depot merger, primarily because it found, based on the pricing evidence, that the sale of office supplies through the office superstore retail channel constituted a relevant product market. ${ }^{28}$ Within that product market, the transaction was a merger to monopoly in many geographic markets and a merger to duopoly in others. The evidence that Staples charged lower prices when it faced rivalry from other office superstore chains convinced the court that non-superstore vendors of office supplies did not provide sufficiently close substitutes for the superstores to constrain office superstore pricing. ${ }^{29}$

In reaching this conclusion, the court highlighted documentary evidence from the merging firms' marketing files about the way they choose price zones for their retail outlets, not the econometric evidence analyzing the same data systematically. But in describing the documents, the court was led, informally, to address some of the same methodological issues that confronted the econometricians. In particular, the district court opinion notes that both cross-sectional and time series (fixed effects) evidence suggested that head-to-head competition between Staples and Office Depot led to lower prices for office supplies, notwithstanding the presence or absence of non-superstore firms selling office supplies nearby.

When the court discussed comparisons across cities, it was relying on cross-sectional evidence. It highlighted "compelling evidence” showing that Staples and Office Depot each charge higher prices in markets where they have no office superstore competition than in markets where they compete with each other and with OfficeMax, and it pointed to "internal Staples documents" comparing prices across prize zones that demonstrate "that Staples charges significantly higher prices ... where it has no office

\footnotetext{
${ }^{28}$ The legal issues surrounding product market definition in Staples and the evidentiary basis for the court's approach to market definition are discussed in Jonathan B. Baker, Stepping Out in an Old Brown Shoe: In Qualified Praise of Submarkets, 68 Antitrust L.J. 203 (2000).
} 
superstore competition than where it competes with the two other superstores.”30 The cross-sectional evidence also included testimony from executives of non-superstore vendors Wal-Mart and BJ's Wholesale Club that Staples prices were lower in locations in which Staples faced competition from other superstores, but did not vary with the presence or absence of non-superstore vendors. ${ }^{31}$

The time series evidence from the merging firms’ documents was similar:

The evidence shows that the defendants change their price zones when faced with entry of another superstore, but do not do so for other retailers. ... There are numerous ... examples of zones being changed and prices falling as a result of superstore entry. There is no evidence that zones change and prices fall when another non-superstore retailer enters a geographic market. ${ }^{32}$

The econometric evidence from the pricing studies was consistent with the cross-sectional and time series documentary and testimonial evidence presented by the government. The estimated price effects from both the cross-sectional and fixed-effect models were quite similar, indicating in this study that the presence of store-specific cost differences did not dramatically effect the estimated pricing behavior of Staples. While not noted by the court, the Staples case provides an example of how econometric evidence can be used to support testimonial and documentary evidence in trial.

${ }^{29}$ The court also rejected the merging firms' efficiency claims as unverified, or at least insufficiently substantiated. It further found that even if credited, those efficiencies were unlikely to be passed on to consumers in the form of lower prices.

${ }^{30}$ Federal Trade Commission v. Staples, Inc., 970 F. Supp. 1066, 1076 (D.D.C. 1997).

${ }^{31} I d$. at 1077.

${ }^{32} I d$. at 1078. 


\section{Figure 1}

\section{STAPRES}

\section{STAPLES' PRICES ARE HIGHER WITH LESS SUPERSTORE COMPETITION}

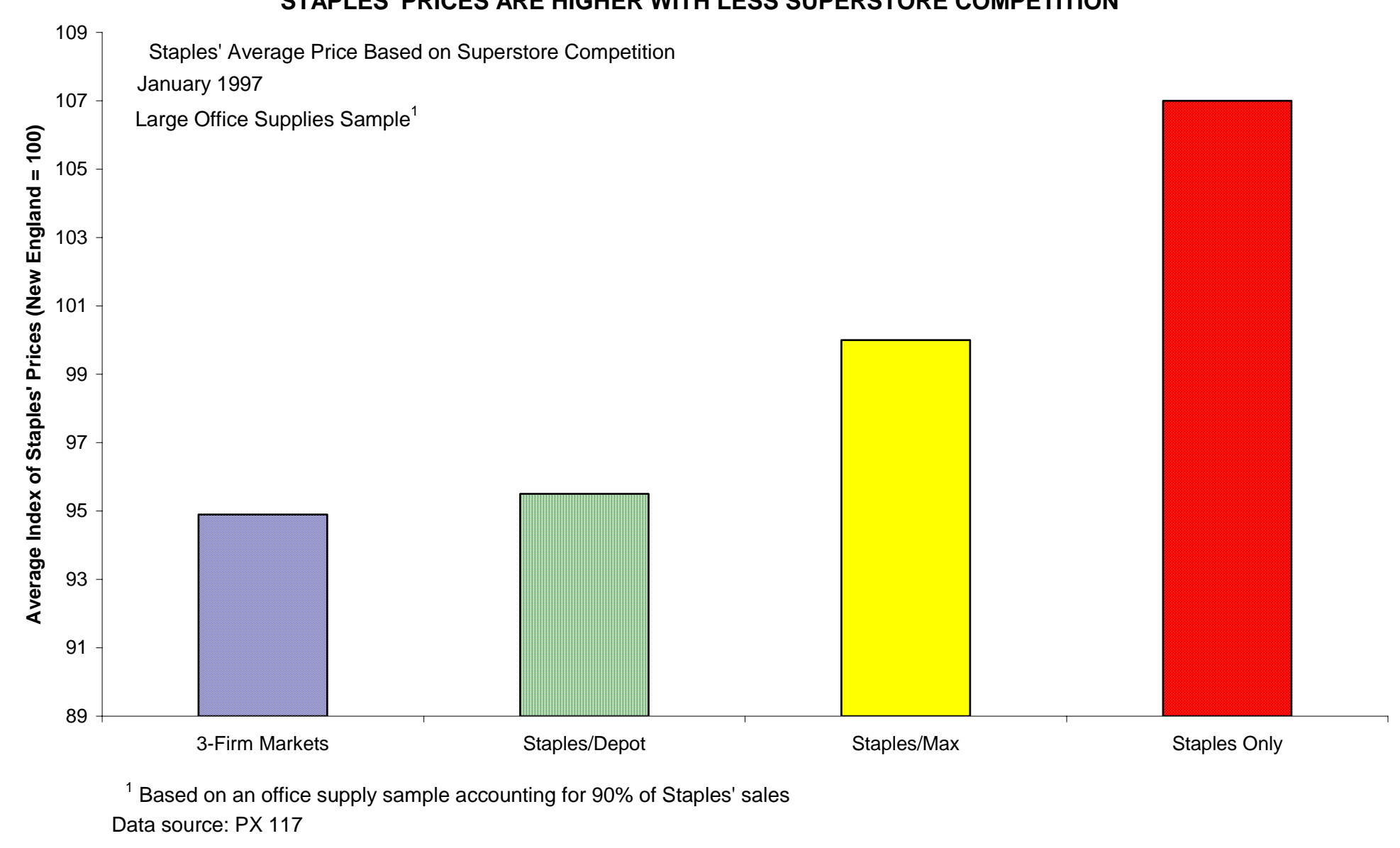


TABLE 1

PX-400: Simulated Impact on Staples Office Products Prices of Eliminating Office Depot: Staples Stores with Some Office Depot Competition

\begin{tabular}{|c|c|c|c|c|c|c|c|}
\hline & Model 1 & Model 2 & Model 3* & Model 4* & Model 5 & Model 6 & Model 7 \\
\hline Simulated Price Change & $1.1 \%$ & $0.8 \%$ & $2.9 \%$ & $3.7 \%$ & $4.0 \%$ & $3.7 \%$ & $8.6 \%$ \\
\hline t-Statistic & 11.19 & 4.79 & 8.88 & 9.16 & 10.33 & 9.12 & 14.99 \\
\hline Observations in Simulation & 6,896 & 1,685 & 1,817 & 1,315 & 1,465 & 1,395 & 3,038 \\
\hline $\begin{array}{l}\text { Sample is: } \\
\text { Parties Sample } \\
\text { Complete Sample }\end{array}$ & Yes & Yes & Yes & Yes & Yes & Yes & Yes \\
\hline $\begin{array}{r}\text { Unit of Observation: } \\
\text { Weekly/Stores } \\
\text { Monthly/Stores }\end{array}$ & Yes & Yes & Yes & Yes & Yes & Yes & Yes \\
\hline $\begin{array}{l}\text { Dependent variable is: } \\
\text { Parties Price Index } \\
\text { Recalculated Price Index } \\
\text { Competitor Variables: }\end{array}$ & Yes & Yes & Yes & Yes & Yes & Yes & Yes \\
\hline $\begin{array}{l}\text { Circle-based** } \\
\text { MSA-based*** }\end{array}$ & Yes & Yes & $\begin{array}{l}\text { Yes } \\
\text { Yes }\end{array}$ & $\begin{array}{l}\text { Yes } \\
\text { Yes }\end{array}$ & Yes & Yes & Yes \\
\hline
\end{tabular}

*Models 3 and 4 are based on the same regression model. Model 3 reports the simulated impact of eliminating Office Depot in markets where either the MSA-based competition data or the Circle-based competition data indicate that a Staples store faces Office Depot competition. Model 4 reports the simulated impact of eliminating Office Depot in markets where both the MSA-based competition data and the Circle-based competition data indicate that a Staples Store faces Office Depot Completion.

**Variables which control for the number of Office Depot, OfficeMax, computer superstores and warehouse clubs within 5 miles, 5 10 miles, and 10-20 miles of the Staples store.

***Variables which control for the number of Staples, Office Depot, OfficeMax, Wal-mart, Sam’s Club, Computer City, BestBuy, Office1Superstore, Costco, BJ's, CompUSA, Kmart and Target stores in the MSA. 